\title{
Application of Conventional and Mutation Approaches in Genetic Improvement of Tuberose (Polianthes tuberosa L.): A Review on Recent Development and Future Perspectives
}

\author{
Mukesh Kumar ${ }^{1 *}$, Veena Chaudhary ${ }^{2}$, Mahesh Kumar ${ }^{3}$, Ujjwal Sirohi ${ }^{4}$ and M.K. Yadav ${ }^{4}$
}

${ }^{1}$ Department of Horticulture, SVPUAT, Meerut, Uttar Pradesh, India

${ }^{2}$ Department of Chemistry, Meerut College Meerut, Uttar Pradesh, India

${ }^{3}$ Department of Agriculture, JBIT Group of Institutions, Dehradun, Uttrakhand, India

${ }^{4}$ Department of Ag. Biotechnology, SVPUAT, Meerut, Uttar Pradesh, India

*Corresponding author: k.mukesh123@yahoo.com (ORCID ID: 0000-0003-4539-9732)

Paper No. 910

Received: 20-06-2021

Revised: 28-08-2021

Accepted: 03-09-2021

\begin{abstract}
In recent days, improved conventional techniques, including division of the bulbs, removal of leaf and flower spikes, standard size of the bulb, and mechanical removal of sprouts, have been used to obtain improved quality planting materials in tuberose. Mutation breeding is also another technique that is used for improvement in tuberose. In mutation breeding, novelty can be created in an already well-established cultivar. Any change in the genes and their expression can be easily measured in the first generation of mutants by selecting desirable characters like flower color, shape, size, fragrance, etc. In the present review, the works carried out on tuberose by various workers worldwide from the last 40 years have witnessed conventional and mutation approaches made in the genetic improvement of tuberose. This review also highlights the role of selection for the identification of desirable traits, self-compatibility, and hybridization approaches made in tuberose species worldwide by several research institutions. Factors that affected mutation efficiency have also been presented and discussed from available data. Overall, the present reviews provide a consolidated account for the application of traditional and mutations approaches and suggest how their implications can be useful for genetic improvement of tuberose.

\section{HIGHLIGHTS}

(0 Inter-specific hybridization plays an important role in the genetic improvement of tuberose. Interspecific hybridization with species like $P$. howardii and $P$. geminiflora would be very effective to achieve colored cultivars in tuberose.

0 Mutation techniques and their implications in breeding programs are efficient and cost-effective tools that can be exploited for genetic improvement in quantitative and qualitative traits like a different color of foliage, number of flowers with various ranges of color, sizes of flowers, and longer spikes.

( There are different types of radiation among the physical mutagens like gamma rays, x-rays, and chemical mutagens like Ethyl Methane Sulphonate (EMS) and Methyl Methane Sulphonate (MMS) are very effective to induce variability in tuberose. Lower concentrations of physical and chemical mutagens can induce variations in foliage and flowering traits of tuberose.
\end{abstract}

Keywords: Tuberose, floriculture; hybridization, interspecific hybridization, mutation, physical mutagens, chemical mutagens

Polianthes tuberosa Linn. commonly known as tuberose, is a monocot bulbous flowering plant that belongs to Amaryllidaceae. Among the bulbous flowering plants, it is one of the most
How to cite this article: Kumar, M., Chaudhary, V., Kumar, M., Sirohi, U. and Yadav, M.K. 2021. Application of Conventional and Mutation Approaches in Genetic Improvement of Tuberose (Polianthes tuberosa L.): A Review on Recent Development and Future Perspectives. IJAEB, 14(03): 277-297.

Source of Support: None; Conflict of Interest: None 
important bulbous flower crops grown under tropical and subtropical regions of the world. In India, tuberose occupies a prime position owing to its popularity as a cut flower, loose flower, perfumery, and secondary metabolites. Tuberose waxy white flowers impregnate the atmosphere with their sweet fragrance with longer keeping quality (Rammamurthy et al. 2010). Instead of ornamental purposes, tuberose flowers are also used in perfumery to source essential oils and aroma compounds (Rammamurthy et al. 2010).

\section{Nomenclature and migration history of tuberose}

Tuberose botanical also known as Polianthes tuberosa L. is cultivated in Mexico before the conquest in 1522. It is one of the many flowers which have come to Mexican culture from the ancient culture of the Nahualt- speaking people. These intensely fragrant, cream-white flowers were known as "Omixochitl" or "bone flower" from the words "omitl", bone, and "xochitl", flower. In Mexico, today tuberose also known as other names i.e. "Nardo", "Azucena", "Amole", and "Amiga de noche". Tuberoses were among the first plants taken back to the Old World. They were revered by the Spanish and often used in their gardens. It is an unanswerable question that tuberose how and when reaches in the way of India and later to Ceylon and elsewhere but it was apparently taken to Europe toward the end of the $16^{\text {th }}$ century. Originally Linnaeus had used the name Polianthus floribus alternis in his Hortus Cliffortianus (1738); later in Species Plantarum, he grouped this and Hyacinthus indicus tuberosus of Gaspard Bauhin and Carls Clusius under the genus Polinathes and the species tuberosa. However, Westland (1881) grown pearly white tuberose in Botanic garden at Birmingham. Wood (1881) described tuberose as hardy and robust collections. Tuberose was also grown on the rock garden in the Tottenham nurseries in severe winter (Anoymous 1981). Howard (1985) described Polianthes of Mexico. Ullrich (1993) attempted to compile a limited bibliography in which illustrations of Polianthes tuberosa appear. The Index Londinensis (Stapf and Worsdell 1929-41), an invaluable bibliography, cites three illustrations of Polianthes tuberosa for the $18^{\text {th }}$ century (Rumph 1797; Kniphof 1764; LaMarck 1997). The oldest known figures in the 'Florentine
Codex' were reported in detail by Trueblood (1973). Ullrich (1993) in his article, has mentioned the early illustrations of tuberose in the European literature for the $19^{\text {th }}$ century and the essential account of Salisbury (1812). Howard (1986) collected a number of quite rare species of Polianthes from Central, Western, southern Mexico and mentioned all with proper accession numbers. Recently, Polianthes tuberosa has been renamed with the name of Agave amica and replaced the family Amaryllidaceae to Asparagaceae (Chase et al. 2016).

\section{Morphology and classification}

Species and cultivars: The genus Polianthes, is endemic to México and comprises about 15 species, including Polianthes tuberosa L. (González-Gutiérrez and Rodríguez-Garay 2016). Datta (2017) reported 15 species, 3 varieties, and a few cultivars in genus Polianthes L. These species are in various colors like white, orange, red, and red to stripe in color. All the species are found in the wild with the exception of Polianthes tuberosa, which has never been found anywhere except under cultivation. Among those botanists whose studies were concerned with the genus Polianthes are Cyrus G. Pringle (1838-1928), Edward Palmer (1831-1911), Cristopher C. Pary (1823-1890) and J.N. Rose (1862-1928 c.f. Emmart Trueblood 1973), and reported that all the species are wild except Polianthes tuberosa which is grown under cultivation. It is a monotypic genus closely related to Bravoa. Some crucial species of Polianthes are Polianthes tuberosa (white), Polianthes palustris (white), Polianthes durangensis (purplish), Polianthes montana (white), Polianthes longiflora (whitish purple), Polianthes plaitphylla (white tinged with red), Polianthes graninifolia (deep red), Polianthes geminiflora (light orange red), Polianthes gracilis (white), Polianthes blissi, Polianthes pringlie (white), Polianthes sesiliflora (white), Polianthes nelsonill (white), Polianthes graminiflora Rose (c.f. Misra and Mahesh 1995). Barba-Gonzalez et al. (2012) also reported various wild Polianthes species including Polanthes geminiflora var. clivicola, Polianthes geminiflora var. graminifolia, Polianthes graminifolia, Polianthes howardii, Polianthes palustris, Polianthes platyphylla, Polianthes pringlei, Polianthes sessiliflora, Polianthes Montana; which were ranged in the color of white, yellow, pink-red, etc. In another study, Barba- Gonzalez et al. (2014) collected and further 
reported 14 species of Polianthes with having colored flowers ranging from scarlet red to yellow. All accessions from the wild and used for the breeding program.

\section{GENETICS AND BREEDING}

\section{Cytology}

Most of the cytological studies, Polianthes tuberosa reported the chromosome number of single-flowered with $2 n=60$, while the double-flowered types have been reported in the range of chromosome numbers $2 n=50,54,60$, and 120 (Whitaker 1934; Satô 1938; Joshi and Pantulu 1941; Sharma and Ghosh 1956; Vij et al. 1982; Schiva and Lanteri 1984; Jayasree et al. 2001; Lin and Shen 2004; Karihaloo 2019). Joshi and Pantulu (1941) observed the haploid number of chromosomes in Polinathes tuberosa as 30, in which 05 chromosomes were large and 25 small. Ayangar (1963) reported that multiple perianth variety was an autotetraploid having a compliment of 120 chromosomes, of which 20 chromosomes were longer and 100 shorter. Schiva and Lanteri (1983) showed variation in chromosome numbers, Single type had $2 n=60$, which was fertile and used for the purpose of perfumery, and $2 n=50$ in infertile and observed in Double type, which is commonly used for cut flower production. Laxmi et al. (1984) analyzed cytomorphological studies in gamma rayinduced mutants of tuberose. Karyotypes of two varieties of Polianthes tuberosa single $(2 n=60)$ and the double $(2 \mathrm{n}=50)$ have been analyzed. Different types of chromosomal configurations were detected during meiotic studies. Joshi and Pantlu (1941) noted the chromosome number $2 \mathrm{n}=60$ in a single type of tuberose. However, they observed two long pairs of a chromosome attached to the nucleus. Sharma and Ghosh (1956) reported mixture of short and long chromosome, and somatic chromosome number for single cultivar was $2 \mathrm{n}=60$ and in double somatic chromosome was $2 n=50$. Out of 60 chromosomes, 10 are longer and in remaining in 50 chromosomes, 24 were medium in size while 26 chromosomes were in shorter size.

Various studies suggested that the species of tuberose hybrid in nature have originated from two different prototypes, one with long chromosomes and the other with the medium and short chromosome (Datta and Banerji 1995). Whitaker (1934) and
Watkins (1936) reported 30 chromosomes in tuberose during meiotic studies. However, Joshi and Pantulu (1941) mentioned the haploid chromosome number of Polinanthes tuberosa was 30, which comprising 05 in longer size and 25 were in small size. They further reported that in the diploid set, two pairs of chromosomes were associated with the organization of the nucleolus. The small bivalent during I \& II metaphase showed secondary pairing - the two nucleoli formed during telophase in unequal size. Sato (1938) found that the karyotype of tuberose was the same as the other genera Bravoa, Agave, Fourcroya, and Beschorneria. Somatic doubling of chromosomes was also observed, which having 20 longer chromosomes and about 100 short ones. Gupta et al. (1984) examined the cytomorphology of two gamma ray induced mutants (Rajat Rekha and Swana Rekha) of Polianthes tuberosa and their respective mother line. Cytological investigations showed that single and double cultivars had 60 and 50 chromosomes, respectively. In another study reported that a double type of tuberose was derived from the single by loss of 10 chromosomes due to abnormal mitotic or meiotic division as reported by (Schiva and Lanteri 1986). Bindhani et al. (2004) analyzed the cytological studies from root meristems and noted 10 large and 50 small chromosomes. The chromosomal analysis of callus cells derived from the fifth sub-culture showed a range of 55 to 58 chromosomes, of which 10 were larger, and the rest were small in sizes while in the seventh subculture exhibited 47 to 52 chromosomes, out of which 10 chromosomes were longer. Karihaloo (2019) used three cultivars of tuberose (Polianthes tuberosa L.), including a single type of flowers (Single), a double type of flowers (Double), and another was in single flowers with variegated leaves. Cytological studies suggested that flower doubling and leaf variegation in tuberose occurred due to gene mutations.

\section{SELF-INCOMPATIBILITY}

Vegetative means bulbs, bulblets commonly propagate tuberose, and generally, there is no seed set. The seed setting in tuberose is quite erratic in the single-flowered cultivar and is not observed in the double type of tuberose flower and the exact cause of sterility is unknown. Joshi and Pantulu (1941) reported that sterility is not due to any defects or deformation in the formation of the pollen grains or 
development of embryo sac. Uma and Gowda (1999) tried to overcome self-incompatibility through some manipulations. They studied bud pollination, used IBA and IAA at the time of pollination to varying and also used gamma irradiated $(0.5 \mathrm{kR})$ pollen. Bud pollination failed to induce fruiting; however, irradiated pollen pollinated two days after anthesis and showed fruit setting up to 4.78 percent with 48.23 percent seed viability. Krishnamurthy and Srinivas (2005) observed histological changes in tuberose during ovule development after crossing in Mexican Single and Pearl Double. They reported that reproductive compatibility stimulates the metabolic activities in the associated tissues leading to the normal development of fruit seed formation while, initial studies attributed seedlessness in single-flowered cultivars of tuberose to sterility (Joshi and Pantulu 1941), and it might be due to self-incompatibility (Shen et al. 1987; Datta 2017). Karihaloo (2019) revealed that the Single type of tuberose was self-incompatible and gametophytic ,with the pollen tubes getting inhibited in style, whereas the variegated type of tuberose was selfcompatible and Single $\times$ Variegated and Single $\times$ Double crosses were compatible. However, fruit and seed set and percent seed germination varied among compatible combinations. Inter varietal hybrids showed functional variation in inflorescence and floral characters, some hybrids having more giant spikes and more flowers/spikes than either of the parents.

\section{APPLICATION OF CONVENTIONAL AND MUTAGENIC APPROACHES FOR GENETIC IMPROVEMENT OF TUBEROSE}

\section{Simple multiplication method}

Due to the lower percentage of germination by seeds, tuberose is generally multiplied by bulbs and bulblets (Hemanta 2015). Chandravadana et al. (1994) produced good quality bulbs of Polianthes tuberosa for seed purposes after two years of evaluation. Similar pattern have been adopted by (Zizzo et al. 1999; Ahmad et al. 2009), where they grew the mother bulb of tuberose and, after harvesting, characterized by different sizes for further multiplication. It is well reported that the larger bulb size produced more number of bulbils and more giant size bulbs as compared to small and medium-sized bulbs, so larger bulbs are recommended for better growth and flowering of tuberose (Ahmad et al. 2009; Raja and Palanisamy 1999; Roa et al. 1991). Sathyanarayana Reddy et al. (1998) noted that larger bulbs produced maximum plant height, more leaves, and maximum flower yield. They further suggested that the smallest bulblets require three to four years to complete the proper size or appropriate level of thickening so larger bulbs should be grown to ensure a profitable plantation. Screening of germplasm and identification of for better quality bulb and bulblets for the reproduction of tuberose have been reported by (Krishnamoorthy 2014; Singh et al. 2013a; Naik et al. 2018).

\section{Hybridization}

It is well-established fact that the development of hybrid depends on genetic variation in crops. Seed reproduction is required to get new varieties of tuberose by hybridization work (Chandravadana et al. 1994; Raja et al. 2003; Rosalind et al. 2018). It takes a long time for germination as well as plant blooms. In addition, the offspring is dispersed due to genetic recombination, often leading to lose of desirable characteristics present in the donor material. Genetic variability is very limited in tuberose, and it is a major constraint in conventional breeding. It is due to mechanisms like self-incompatibility, dichogamy, and poor seed setting in tuberose (Shen et al. 1987; Sreethramu et al. 2000). There are several cultivars in tuberose, including a double called "The Pearl or Dwarf Pearl Excelsior", a single type, usually called "Mexican Single" but sometimes "Maxican Ever blooming," and one or more variegated forms. Polianthes hybridization works mainly concentrated with the tuberose species (Polianthes tuberosa L.) due to its ready availability, longer spikes, larger size flowers, and outstanding fragrance. Only a few reports on hybridization work are available viz; Bundrant (1985) collected tuberose germplasm from a local nurseryman in San Antonio, Texas and started work on hybridization in 1972 when the only one was the one one 'Mexican Single' cultivar was in commence. A total of three cultivars were successful developed by the hybridization work including $P$. $x$ blissii, $P . \times$ bundrantii $(P$. tuberosa $\times P$. howardii $)$ and $P$. tuberosa $\times P$. (Manfreda) maculosa. The 
genus Polianthes includes those species originally included in Polianthes, but all those formerly placed in the genera Bravoa, Pseudobravoa, Manfreda, Prochnyanthes Runyonia, and the herbaceous species of Agave (Shinners 1966). Traub (1953) concluded that hybridization is possible between Polianthes, Prochnyanthes, Pseudobravoa genus. The first hybrid in this group was produced using Polianthes (Bravoa) genminiflora and Polianthes (Prochnyanthe) bulliana in 1899 by (Worsley 1911). However, the first cross in the tuberose was reported in 1911 as Polianthes $\times$ blissii, a cross between P. geminiflora and P. tuberosa. Verhock- Williams (1975) did a cross between Polianthes (Manfreda) virginica with Polianthes tuberose and obtained seeds from a cross between single and double cultivars. Howard (1977) developed fragrant colored flowers in tuberose by hybridization with various new Polianthes species. The work was initiated after the motivation of earlier work carried out by Worsley (1911), who developed Polianthus $\times$ Blissi Worsdey Hybrid. The hybrid was intermediate between its parents, having the delicious fragrance of male parent Polianthes tuberosa combined with the rich rose pink color of a female parent like Polianthes geminiflora. Howards (1978) further started an experiment to develop color and fragrance in hybrids with characteristics of the tuberose. A new hybrid $P . \times$ Bundrantii $(P$. tuberosa $\times$ P. howardii) was developed similar to commonly grown tuberose. The hybrid flowers had maroon interiors and rose pink exteriors tipped green with fragrance. Two major cultivars, including white-colored cultivars, namely 'Single' and 'Double' were cultivated for commercial production. Crosses and backcrosses among Polianthe tuberosa 'Single'and 'Double', P. $\times$ howardii and $P . \times$ blissii were made and obtained several hybrids, including pink reddish-purple, purple, orange, and yellow flower colors. However, the long spikes of these colored hybrids were only suitable for cut flowers. Four hybrids showing dwarf plant types were reselected as pot and bedding plants (Shen et al. 2003). Inter-specific hybridization plays an important role in genetic improvement in tuberose. Inter-specific hybridization studies have been conducted by Shen et al. (1987) and Srinivas et al. (1995). They confirmed the utility of intraspecific hybridization in developing improved tuberose cultivars. However, interspecific hybridization with species like P. howardii and P. geminiflora would be necessary to develop cultivars with truly colored flowers which is one of the main objectives of tuberose breeding as suggested by earlier workers (Shen et al. 1997; Huang et al. 2001, 2002; Datta 2017). The heterozygous population present in each inter-varietal cross caused wide variation in the flowering and yield traits, resulting in low and high yielding hybrids from a single cultivar (Bharathi and Kirthishree 2019). Bharathi and Kirthishree (2019) hybridized as single cultivars as female and male parent and double cultivars as the male parent. A total of 224 hybrid seedlings were developed by eleven cross combinations. The flower buds with green tinges were noticed on sixteen hybrids produced in five cross combinations. The crosses of variegated $\times$ Arka Suvasini resulted in a maximum number of hybrids with a green tinge on the flower bud. A total of sixteen hybrids with green tinges on flower buds were subjected to performance evaluation. To date, few hybrids of Polianthes tuberosa L. have been developed, including Shringar, Suvasini (both developed from a cross between (Single $\times$ Double), Prajwal (Shringar $\times$ Mexican Single), Vaibhav (Mexican Single x IIHR - 2), Arka Nirantara, (Single $\times$ Double) etc. Karihaloo (2019) reported that progenies obtained from Single $x$ Variegated and Single $\times$ Double and found superior to either parent in characters like spike length and a number of flowers/spike. Also, flowers in some hybrids showed a deeper pink color on outer tepals than in the parents, which is a desirable ornamental character.

\section{Mutation breeding in tuberose}

Mutation breeding is an efficient and cost-effective technique that can be exploited for genetic improvement for various economic characters in tuberose. In tuberose, primary objectives are various flower colors, fragrance, essential oil, longer spikes with larger flowers, etc. Since tuberose is mainly propagated by vegetative methods and mutation breeding can change one or a few characters of an otherwise outstanding variety without altering the unique part of the genotype (Datta 2014). Common mutagens which are used in tuberose can be classified into two groups i.e. physical mutagens and chemical mutagens. Among the physical mutagens, different types of radiations like gamma rays, X-rays, alpha-particles, beta- 
particles, ultraviolet rays, and fast and thermal neutrons are considered. Instead of it, chemical mutagens include Ethyl Methane Sulphonate (EMS), Methyl Methane Sulphonate (MMS), ethylene amines, 5-Bromo Uracile, 2-Amino purine, acriflavin, proflavin, nitrous acid, hydroxylamine, sodium azide, etc. are commonly used. In mutation breeding of tuberose, physical mutagens have been commonly used for the development of new varieties. Among all physical mutagens, gamma radiations are preferable due to their properties like sparsely ionizing, deeply penetrating and nonparticulate, Abraham and Desai (1976a) and Gupta et al. (1984). In India, Younis and Abraham (1975) started the work on tuberose mutation for inducing genetic and morphological variability by gamma irradiation. Very little has been done on mutation breeding in tuberose for its genetic improvement. Mutation breeding in tuberose has been conducted by a few scientists and observed different types of morphological abnormalities like changes in shape size, margin apex, fission and fusion of leaves, and chlorophyll variegation in leaves while using mutagen as gamma rays (Abraham and Desai 1976b; Younis and Abraham 1975; Krasaechai 1992; Shukla and Datta 1993 and Navabi et al. 2016; Abhangrao et al. 2019; Jyoti et al. 2019; Kutty et al. 2020), EMS (Singh et al. 2015), X-rays (Kainthura et al. 2016) and gamma rays, $x$-rays and EMS (Kainthura and Srivastava 2015; Pooja et al. 2016; Kayalivizi 2016 and Kayalivizi 2017). Some critical mutation studies with different mutagens are briefly discussed in (Table 1)

\section{Effect of gamma rays on growth and flowering parameters in tuberose}

Among the different mutagens, Ionizing radiations, particularly gamma rays, have been used to develop novel ornamental varieties through induce mutation (Patil and Patil 2009). Lower doses of gamma rays have been useful for changing the vegetative characters in tuberose (Shukla and Datta 1993); Estrada-Basaldua et al. 2011; Navabi et al. 2016; Sah et al. 2017) and Sharavani et al. 2019). Higher doses of gamma rays decreased in plant height (Fig. 1). Two chlorophyll variegated mutants in tuberose using $2.5 \mathrm{Krad}$ gamma rays were developed and released by (Gupta et al. 1974). Patil et al. (1975) obtained bolder flower, higher flower tube, and larger flower with $.5 \mathrm{Kr}$ dose of gamma rays while
1.5 $\mathrm{Kr}$ produced bifurcated stalk, leaves with ivory colored and three flowers at one place. Younis and Borham (1975) used 500 to $3000 \mathrm{krad}$ gamma rays and induced genomic and morphological variability in tuberose. Krasaechai (1992) irradiated bulblets with gamma rays at $0,5,10,15,20,25$, and 30 Gy at $7.12 \mathrm{~Gy} /$ minute and observed that $10 \mathrm{~Gy}$ or above dose of gamma rays reduced growth rate and percentage of bulblet survival was effectively zero after 15 or 20 weeks for those irradiated with 25 or 30 Gy, respectively. All irradiated plants had leaf chimeras but unchanged flower color. Datta (1993) also treated single and double tuberose (Polianthes tuberose L.) by gamma radiation. Morphological abnormalities in tuberose leaves and chromosomal aberrations during root tip mitosis were caused by gamma radiation in both single and doubleflowered types. Ali (2002) concluded that low radiation intensity gave better results in growth characteristics like sprouting percentage, plant height, and number of leaves per plant compared to high-intensity radiations. Krishnan et al. (2003) treated the bulbs of four tuberose cultivars viz. Single, Double, Shringar, and Suvavini with gamma radiations (5.0 to $25 \mathrm{~Gy}$ ). Based on growth parameter and floral characters, four mutants were isolated viz., dwarf mutant, high tiller mutants, nonflowering mutants, and compact inflorescence mutants and also retained these characters in $\mathrm{vM}_{2}$ generation. Guo et al. (2009) noted that single petal tuberose was more tolerant to gamma rays irradiation than double petal variety. By analyzing isoenzyme by polyacrylamide gel electrophoresis, 20 and 25 Gy treatments promoted the expression of peroxide isoenzyme, ester isoenzyme, and catalase isoenzyme. According to the results of agronomic traits and isoenzyme analysis, 20 Gy gamma rays was suitable for two varieties of Polianthes mutagenic L. Singh et al. (2011) observed that plant height and several leaves significantly decreased with 2 and $3 \mathrm{kr}$ gamma rays irradiation in $\mathrm{VM}_{1}$ and $\mathrm{VM}_{2}$ generations while in $\mathrm{VM}_{1}$ generation, flowering was delayed with 1 and $2 \mathrm{kr}$ gamma irradiation, respectively. The number of florets per spike in $\mathrm{VM}_{1}$ and $\mathrm{VM}_{2}$ was lower than in control. In $\mathrm{VM}_{1}$ generation, the weight of the spike was decreased while the weight of 100 flowers and the number of bulbs increased with $1.0 \mathrm{kr}$ of gamma rays. EstradaBasaldua et al. (2011) noted that seedlings obtained from in vitro and in vivo plants exposed by gamma 
Table 1: Mutation studies in tuberose (Polianthes tuberosa L.)

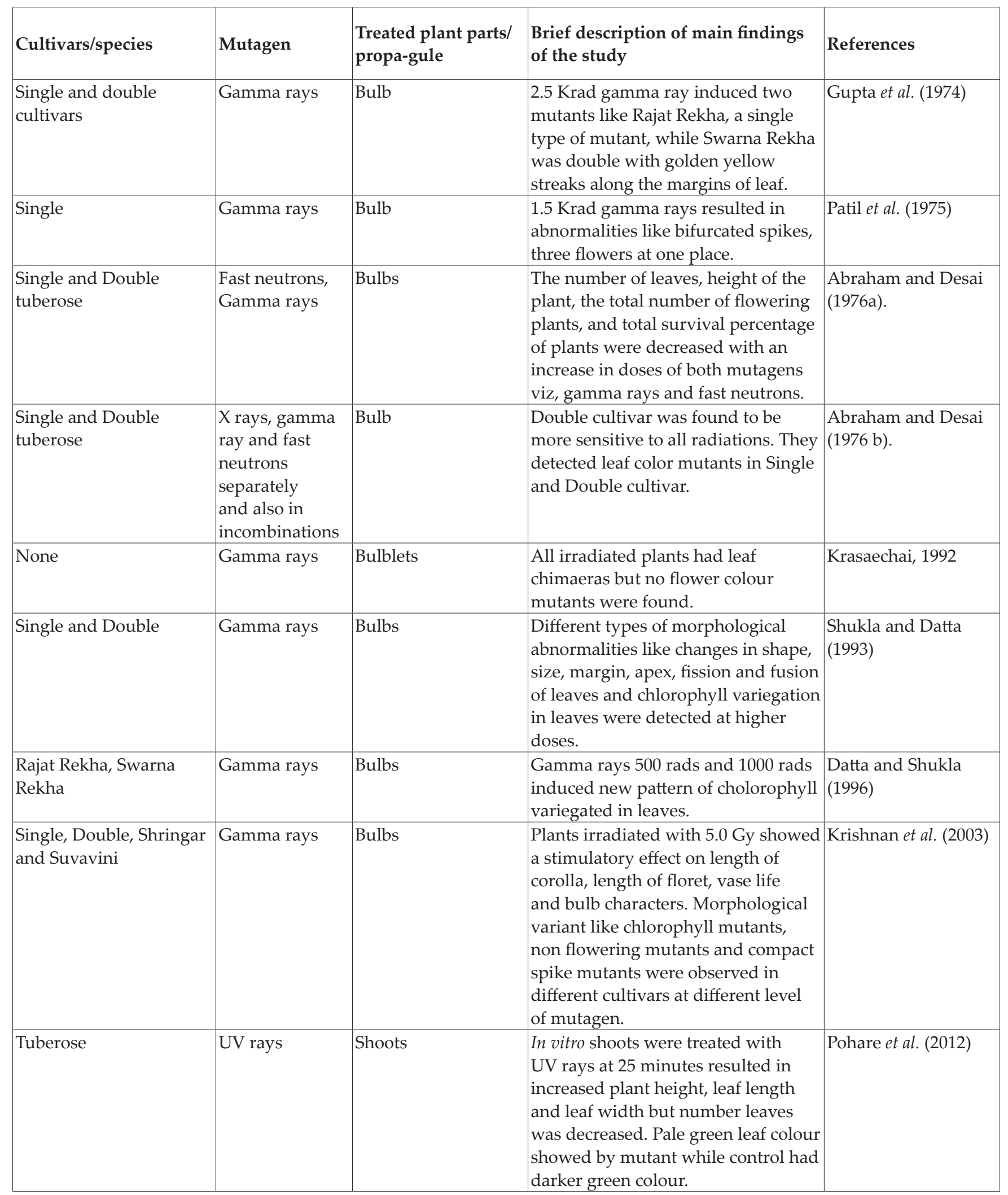




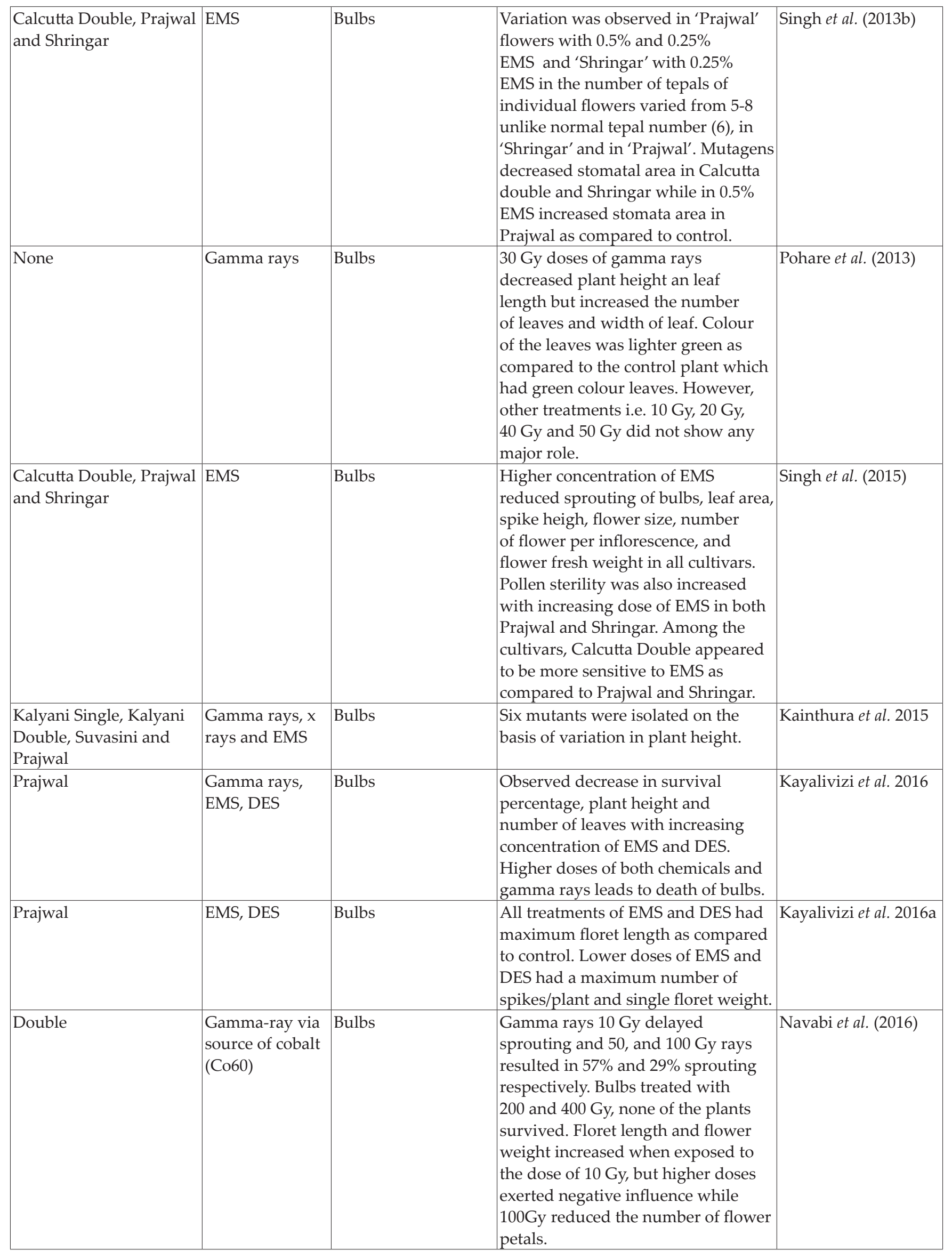




\begin{tabular}{|c|c|c|c|c|}
\hline $\begin{array}{l}\text { Kalyani Single Kalyani } \\
\text { Double Suvasini, } \\
\text { Prajwal }\end{array}$ & $\begin{array}{l}\text { Gamma rays, } x \\
\text { rays and EMS, }\end{array}$ & Bulbs & $\begin{array}{l}\text { Different varieties showed variation } \\
\text { at different doses of mutagens as } \\
\text { compared to respective control in } \\
\text { terms of growth parameters like } \\
\text { plant height, plant spread and } \\
\text { flowering parameters such as length } \\
\text { of spike, rachis and number of } \\
\text { florets/spike etc. }\end{array}$ & Pooja et al. 2016 \\
\hline Prajwal & $\begin{array}{l}\text { Gamma rays, } \\
\text { EMS, DES }\end{array}$ & Bulbs & $\begin{array}{l}\text { Different mutagens showed variation } \\
\text { in various growth and flowering } \\
\text { parameters as compared to the } \\
\text { mother plant in M1V2 generation. }\end{array}$ & Kayalivizi et al. 2017 \\
\hline Prajwal & $\begin{array}{l}\text { DES, EMS, } \\
\text { gamma rays }\end{array}$ & Bulbs & $\begin{array}{l}\text { Lower dose of DES } 20 \mathrm{mM} \text { emerged } \\
\text { earlier spike, while DES } 25 \mathrm{mM} \text { had } \\
\text { maximum floret length and spike } \\
\text { length. Gamma rays } 0.5 \mathrm{kR} \text { produced } \\
\text { maximum flower diameter and } \\
\text { maximum rachis length. }\end{array}$ & $\begin{array}{l}\text { Kayalvizhi et al. } \\
(2017 a)\end{array}$ \\
\hline \begin{tabular}{|l|} 
Shringar, Calcutta \\
Double, Vaibhav, \\
Pune Local Single, \\
Arka Nirantra, Sikkim \\
Selection, Prajwal, \\
Hyderabad Single, Phule \\
Rajani Single, Mexican \\
Single, ACC No.7, \\
GKTC-4 and ACC No.9
\end{tabular} & Gamma rays & Bulbs & $\begin{array}{l}\text { Did not show any improvement } \\
\text { in growth, flowering and bulb } \\
\text { parameters when using gamma rays } \\
\text { for bulb treatment. } 4 \mathrm{kR} \text { doses of } \\
\text { gamma rays stopped sprouting due } \\
\text { to lethal effect. However the bulb } \\
\text { treated with } 2 \mathrm{kR} \text { doses of gamma } \\
\text { ray inhibited all growth, flowering } \\
\text { and bulb parameters except earlier } \\
\text { flowering. }\end{array}$ & Sah et al. (2017) \\
\hline Prajwal & $\begin{array}{l}\text { EMS with } \\
\text { three dipping } \\
\text { durations } \\
\text { (5minutes, } 4 \\
\text { hours and } 8 \\
\text { hours }\end{array}$ & Bulbs & $\begin{array}{l}0.25 \% \text { EMS with dipping time } 8 \\
\text { hours was found to be effective in } \\
\text { increases of plant height, number of } \\
\text { leaves and reduced length of leaves. } \\
\text { The interaction effect was found } \\
\text { highest in treatment combination } \\
0.25 \% \text { EMS with } 8 \text { hours dipping } \\
\text { duration for growth parameters. }\end{array}$ & Yadav et al. (2018) \\
\hline Phule Rajni & Gamma rays & Bulbs & $\begin{array}{l}\text { Lower dose @ } 0.5 \text { krad increased } \\
\text { stem diameter and number of } \\
\text { unopened florets. However, } 2.5 \\
\text { krad doses of gamma rays increased } \\
\text { the flower weight as compared to } \\
\text { control. }\end{array}$ & $\begin{array}{l}\text { Abhangrao et al. } \\
(2019)\end{array}$ \\
\hline Prajwal and Phule Rajani & Gamma rays & $\begin{array}{l}\text { Freshly harvested } \\
\text { bulb, three weeks } \\
\text { after uprooting } \\
\text { and six weeks after } \\
\text { uprooting }\end{array}$ & $\begin{array}{l}\text { The mutant plants showed } \\
\text { significant differences in } \\
\text { morphological in various growth } \\
\text { and flowering traits when bulbs } \\
\text { were treated at different stages. }\end{array}$ & Jyoti et al. (2019) \\
\hline
\end{tabular}




\begin{tabular}{|c|c|c|c|c|}
\hline Hyderabad Single & Gamma rays & Bulbs & $\begin{array}{l}\text { There was significant reduction in } \\
\text { all floral attributes in treated plants } \\
\text { as compared to control. Gamma } \\
\text { rays showed significant reduction } \\
\text { in flowering which was up to } 20 \text { Gy } \\
\text { and beyond } 20 \text { Gy, no flowering was } \\
\text { recorded. }\end{array}$ & Sharavani et al. (2019) \\
\hline $\begin{array}{l}\text { Calcutta Double and } \\
\text { Arka Nirantara }\end{array}$ & $\begin{array}{l}\text { Gamma rays, } \\
\text { EMS }\end{array}$ & $\begin{array}{l}\text { Bulb (Gamma rays) } \\
\text { Seeds (EMS) }\end{array}$ & $\begin{array}{l}20 \text { Gy gamma rays produced white } \\
\text { colour in the leaf margin. This new } \\
\text { leaf mutant is named as Pranta } \\
\text { (margin) Rekha (streak). }\end{array}$ & $\begin{array}{l}\text { Singh and } \\
\text { Sadhukhan, (2019) }\end{array}$ \\
\hline Calcutta Single & Gamma rays & Tubers & $\begin{array}{l}\text { Lower dose (10 Gy) enhanced } \\
\text { growth rate, higher volatile content } \\
\text { in comparison with control plants. } \\
10 \text { Gy and } 15 \text { Gy rays irradiated } \\
\text { plants displayed seven tepals against } \\
\text { control flowers where the number is } \\
\text { usually six. }\end{array}$ & Kutty et al. (2020) \\
\hline
\end{tabular}

radiation dose @5 Gy, had similar development to the control's treatment, and plants development appeared to decrease when increasing the radiation dose. The plants exposed at $30 \mathrm{~Gy}$, died and did not develop roots, so these plants survived until their reserves ran out; while acclimated plants exposed to 30 Gy survived because they developed viable roots as a possible effect of the exposure of irradiated tissue to plant growth regulators (NAA and $\mathrm{BA}$ ) present in the culture medium during the stage of in vitro development. Pohare et al. (2013) observed that plants irradiated with 30 Gy rays decreased in plant height and leaf length while the increased number of leaves and color of leaves was light green as compared to the control plant. Navabi et al. (2016) noted the delay in sprouting with $10 \mathrm{~Gy}$. However, higher doses of gamma rays like 50 and 100 Gy decreased in sprouting viz: $57 \%$ and $29 \%$, respectively. Sah et al. (2017) observed no improvement in fourteen varieties of tuberose when bulbs were treated with gamma rays. However, the bulb treated with $2 \mathrm{kR}$ dose of gamma-ray inhibited all growth, flowering, and bulb parameters but emerged earlier flowering than control. Abhangrao et al. (2019) suggested that lower doses of gamma rays are beneficial for obtaining mutants. Seven mutants induced at a lower dose of gamma rays in $\mathrm{VM}_{1}$ generation, i.e., early mutant, tall mutant, flower bud color mutant, big flower size mutant, number of petal increased mutant, number of spikes increased mutant and green tinge on flowers tip mutant. Jyoti et al. (2019) used gamma rays with two cultivars and three stages of harvested bulbs, including freshly harvested bulbs $\left(B_{0}\right)$, three weeks after uprooting $\left(B_{1}\right)$, and six weeks after uprooting $\left(\mathrm{B}_{2}\right)$. 7.5 Gy dose of gamma rays induced new mutants in VM1 generation viz., tall flowering mutant, dwarf mutant, flower color mutant, double spike head mutant even though these mutant were novel but not found stable in next generation. Among the harvested stages of bulbs, Freshly harvested bulbs of both the tuberose cultivars, i.e., Prajwal and Phule Rajani had highly suitable for mutation induction either in vivo or in vitro conditions. Sharavani et al. (2019) recorded maximum values for all floral attributes with control followed by $\mathrm{T}_{1}$ (5 Gy). Increasing the dose of gamma rays from $10 \mathrm{~Gy}$ reduced in vegetative growth of tuberose. Bulbs treated with 20 Gy gamma rays induced variegated leaves and albino mutants. Kutty et al. (2020) reported that lower dose (10 Gy) enhanced growth rate, emerged earlier flowering, higher volatile content compared to control plants in both $M V_{1}$ and $M V_{2}$ generation while, higher doses, i.e., 20 Gy and 25 Gy took a longer time to flower initiation. Plants obtained from $10 \mathrm{~Gy}$ and 15 Gy rays displayed seven tepals against control flowers where the number is usually six. A dose of $10 \mathrm{~Gy}$ induced a slightly higher number of new tubers while 15 Gy, 20 Gy, and 25 Gy decreased tuber formation. The flowers obtained from 10 Gy irradiation dose had significantly higher total benzenoids and total terpenoids in $\mathrm{MV}_{1}$ generation. The amount of methyl 2-amino benzoic acid, 1 , $H$-indole was higher in floral emitted profile from both plants irradiated with $10 \mathrm{~Gy}$ and $15 \mathrm{~Gy}$. It 
was further noted that flowers of $\mathrm{MV}_{2}$ generation developed from 10 Gy irradiation dose showed an enhancement in volatiles emission.

\section{Effect of EMS on growth and flowering parameters of tuberose}

According to International Atomic Energy Association (IAEA) database, over $80 \%$ of the registered mutant plant varieties have been released by chemical mutagenesis such as alkylating agents (Oladosu et al. 2016). Among the alkylating agents, three compounds viz: Ethyl Methane Sulphonate (EMS), 1-methyl-1-nitrosourea, and 1-ethyl-1nitrosourea, are commonly used for inducing the variability in crops, including tuberose, which accounts for $64 \%$ of the total varieties (Wani et al. 2014). Singh et al. (2013b) induced variations such as anatomical changes with the structural organization of stomata in three genotypes of tuberose as compared to the untreated. Singh et al. (2015) stated that a higher dose of EMS reduced sprouting of bulbs, leaf area, spike height and diameter, flower size, number of flowers per inflorescence and fresh flower weight in two cultivars of tuberose as compared to untreated control. However, the number of leaves significantly increased in most EMS treatment. The number of leaves significantly increased in most EMS treatment and the maximum number of leaves produced by $0.5 \%$ EMS treatment. Pollen sterility had also increased with increasing doses of EMS in both Prajwal and Shringar. Among the cultivars, Calcutta double appeared to be more sensitive to EMS as compared to Prajwal and Shringar. Kaintura et al. (2018) studied the mutagenic effect of EMS on four cultivars of tuberose (Polianthes tuberosa Linn.) cv. Kalyani Single, cv. Kalyani Double, cv. Suvasini and cv. Prajwal by treating them with 2 doses of EMS $(0.1 \%$, $0.2 \%$ ). Both doses of EMS created morphological variation related to a floral character in the cultivar of Prajwal and Suvasini. The lower doses of EMS $(0.1 \%)$ increased the floral size of few florets within a spike. Yadav et al. (2018) standardized the dipping duration of bulbs with EMS concentration. The 8 hours dipping duration was most effective, and reduce the length of leavesin increasing plant height, number of leaves, and length. The interaction effect was found highest in the combination of $0.25 \%$ EMS with 8 hours dipping duration.

\section{Comparative effect of different mutagens on growth and flowering parameters in tuberose}

Abraham and Desai (1976a) examined the effect of lethality in bulbs of single and double type of tuberose with different sizes when treated with fast neutrons and gamma rays. They reported that bulb size is not very critical in determining lethality in both the varieties. In another experiment, Abraham and Desai (1976b) used x rays, gamma-ray and fast neutrons separately and in combinations for mutation in the single and double type of tuberose. Double cultivar was found to be more sensitive to all radiations. Leaf color mutants were also detected in single and double-type cultivars. Kayalvizhi et al. (2016a) reported that lower doses of DES and EMS had higher values for morphological and floral parameters than the untreated control. Kayalvizhi, (2016) noted that increasing the doses/

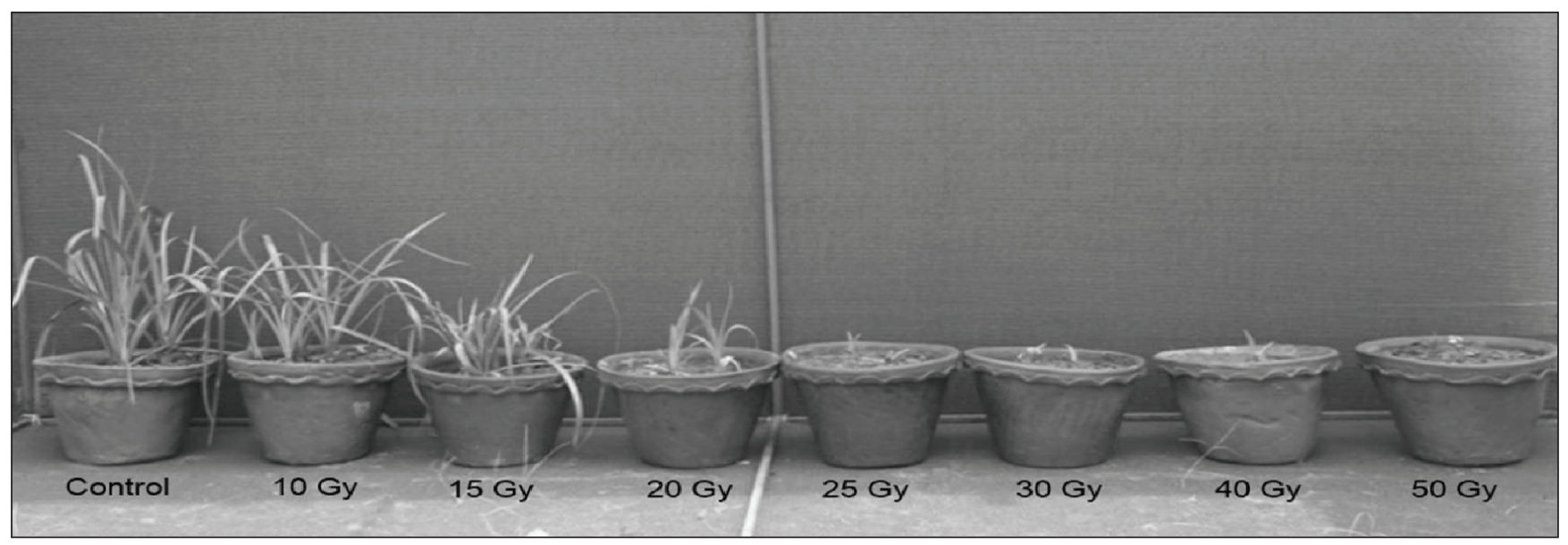

Fig. 1: Effect of gamma rays on vegetative growth of tuberose (Kutty et al. 2020) 
concentrations of mutagens decreased in sprouting percentage, survival percentage, plant height, and a number of leaves per plant. Abnormal reductions in the survival of bulbs were also observed with an increase in concentrations of EMS and DES. However, gamma ray treated bulbs were analyzed only for sprouting and survival percentage and noted very slow growth in treated plants. Singh and Sadhukhan, (2019) treated the bulbs of two varieties namely Calcutta Double and Arka Nirantara of tuberose with gamma rays and EMS. 10kr gamma rays resulted in tall and branched spike mutant The third mutant had unique chlorophyll variegated leaf mutant designated as Pranta Rekha with green leaves with white margins. One dwarf and other with altered floral characteristics resulted from 1\% EMS treatment from the cv. Arka Nirantra. In two mutagens, gamma rays showed more mutagenic efficiency than EMS. (Kayalvizhi et al. 2017) observed variable results when employed physical and chemical mutagens. $1.0 \mathrm{kr}$ gamma rays exhibited the absence of pink tinge on the tip of the floret while $1.5 \mathrm{kr}$ doses of gamma rays resulted in leaf abnormalities such as merging of two leaves. 2.0 $\mathrm{kr}$ doses of gamma rays resulted in mutants with leaf vein, single floret per node, fusion of two florets, uneven size of florets and broader stamen. However, $2.50 \mathrm{kR}$ gamma rays produced in two rows of florets in a single type variety while, $15 \mathrm{mM}$ DES showed sickle shaped leaf and tepal elongation and $20 \mathrm{mM}$ DES induced mutants with crinkled, lobed leaf, leaf vein, tepal serration, sharp and bent floret tip and pink color of whole bud. The bulbs treated with $25 \mathrm{mM}$ DES induced leaf vein, bent floret tip while $30 \mathrm{mM}$ DES resulted in mutant exhibiting leaf vein and spike abnormalities. The concentration of $30 \mathrm{mM}$ EMS induced in varying size of florets. However, in another study with the same mutagens, Kayalvizhi ( 2017a) showed reduced expression in treated populations than the control (untreated population) for most of the morphological and floral characters. Expression of the morphological characters namely plant height, number of leaves, leaf length, leaf width, leaf thickness and floral characters, was higher in the lower doses and lower in the higher doses in $M_{1} V_{2}$ generation. Kainthura et al. (2015) induced the variability with gamma rays, $x$ rays, and EMS in four varieties of tuberose including Kalyani Single, Kalyani Double, Suvasini and Prajwal by using. Genotype Prajwal treated with EMS $(0.2 \%)$, increased in number of petals per floret while irradiated with $1.2 \mathrm{kr}$ x-rays produced fusion of two florets into one. Pooja et al. (2016) recorded similar observations, who induced variability in tuberose by gamma rays, $x$ rays, and EMS. Lower doses had a significant simulative effect on vegetative parameters viz., sprouting percentage, days to sprouting while the parameter about survival rate, leaf length, number of spikes per plant, florets per spike, flowering duration and vase life were observed with decreasing trend. Higher doses of all mutagens had detrimental effects on the vegetative and floral characters. Mutants exhibited variation from the parent plant concerning the vegetative characters.

\section{FACTORS AFFECTED THE MUTATION EFFICIENCY}

\section{Clear objective}

Clear objectives and specific trait should be in mind before starting the work on mutation breeding. It is most important way to conduct with a higher chance of success than a program designed to select more than one trait. To induce the variability in tuberose, Estrada-Basaldua et al. (2011) treated the tubers with 60Co gamma rays and treated bulbs were cultured under in vitro. Increased radiation doses reduce the development of tuberose plants, both in plants developed from acclimated buds, as in those developed from tubers established in vivo. Irradiated plants showed a greater variation in the length and width of leaves than non-irradiated plants.

\section{Genotype}

Abraham and Desai (1976b) isolated leaf color mutants in single and double cultivar when irradiated the bulbs with $x$ rays, gamma ray and fast neutrons separately and in combinations. Singh et al. (2013b) noted decrease in the stomatal area in Calcutta Double and Shringar with an increased concentration of EMS while EMS 0.25\% increased in the stomata area in Prajwal cultivar. EMS treatment showed in the changes of the internal anatomical structure of the scape of all varieties exhibited a certain amount of dissimilarity concerning distribution pattern, number and arrangement of vascular bundles and mechanical tissues as 
compared to untreated plants. Singh et al. (2015) observed a significant reduction in sprouting of bulbs, leaf area, spike height and diameter, flower size, number of flower per inflorescence, and fresh flower weight in all cultivars treated with higher dose $(1 \%)$ of EMS as compared to lower concentration and untreated control. Prajwal had great pollen sterility $(8.57 \%)$ followed by Shringar $(2.33 \%)$; however, and sterility could not be assessed in cv. Calcutta is double due to lacking of effective pollen-bearing stamen. Kainthura and Srivastava (2015) examined the irradiated effect in four tuberose varieties viz., Kalyani Single, Kalyani Double, Suvasini and Prajwal with two doses each of gamma rays viz., $(0.5 \mathrm{Kr}, 1.5 \mathrm{Kr})$, x-rays $(0.6 \mathrm{Kr}, 1.2 \mathrm{Kr}$ ) and Ethyl Methyl Sulphonate (0.1 percent, 0.2 percent) along with the untreated sample (control). Among the genotypes, Prajwal and Suvasini induced maximum plant height with different mutagens compared to Kalyani Single and Kalyani Double. In another study, Kainthura et al. (2016) noted that Kalyani Single emerged earlier sprouting with x rays @12 gy while Kalyani Double emerged earlier sprouting with $0.1 \%$ EMS and Prajwal showed earlier sprouting with 5Gy gamma rays as compared to control while cultivar Suvasini emerged late sprouting than control. As per sprouting percentage, Kalyani Single showed maximum sprouting with 6 gy $x$ rays and EMS $0.2 \%$ while Suvasini was at par with control, however, cultivar Prajwal had maximum sprouting with EMS $0.2 \%$ while Kalyani Double took more days for sprouting as compared to control. Singh and Sadhukhan (2019) treated the bulbs of Calcutta Double Arka Nirantara with different doses of 60 Co gamma rays while only Arka Nirantara seeds were treated with various concentrations of EMS. Cultivar Calcutta induced variegated leaf mutant, branched and tall mutant while Arka Nirantra produced flower mutant in tuberose. Sah et al. (2017) observed that genotypes ACC No.7 treated with 2 $\mathrm{kR}$ dose of gamma rays emerged earlier flowering at least half days as compared to control while GKTC-4 resulted in late flowering in same treatment but also earlier than control. Rachis length was decreased in all mutant cultivars as compared to their respective control, while the intermodal length was longer in mutant developed from Vaibhav as compared to control. Mutant GKTC-4 showed more length of floret and maximum duration of flowering as compared to control. Mutant Sikkim Selection had a maximum number of bulbs/hill, higher bulb weight, and more diameter of bulb compared to control.

\section{Type of materials}

Jyothi et al. (2019) examined two varieties i.e. Prajwal and Phule Rajani, with three types of bulbs: freshly harvested bulb, three weeks after uprooting, and six weeks after uprooting bulbs. Both cultivars' freshly harvested bulbs were found highly suitable for mutation induction either in vivo or in vitro condition. Singh and Sadhukhan (2019) used gamma rays to treat the bulbs while EMS was used to treat the seeds of tuberose. Among the physical and chemical mutagens, bulbs treated with gamma rays induced more mutant than seed treatment.

\section{Type of mutagens}

Kainthura and Srivastava (2015) examined the performance of gamma rays with $1 \mathrm{Kr}$ and1.5 Kr, X-rays $0.6 \mathrm{Kr}$ and $1.2 \mathrm{Kr}$ and EMS $0.1 \%$ and $0.2 \%$ and untreated as a control. Among the mutagens, EMS $(0.2 \%)$ and1.2 $\mathrm{Kr}$ X-rays was found superior for inducing the mutants in tuberose. Kayalvizhi et al. (2017) used gamma rays (0.5, 1.0, 1.5, 2.0 and $2.5 \mathrm{kR})$, DES $(15,20,25$ and $30 \mathrm{mM})$, EMS $(30,45$, 60 and $75 \mathrm{mM}$ ) to examine the effect mutagens in $M_{1} V_{2}$ generation. Among the physical and chemical mutagens, $1.0 \mathrm{kR}$ gamma ray and chemical mutagens like $15 \mathrm{mM}$ DES was found effective for induction of mutants in tuberose. Singh and Sadhukhan (2019) used two types of mutagens i.e. gamma rays and EMS to treat the bulbs and seeds of tuberose. Gamma rays exhibited more mutagenic efficiency than EMS.

\section{Radio-sensitivity test}

Sambandamurthi, (1983) determined the sensitivity test in tuberose when EMS and DES was used as mutagens. The LD50 values optimized for tuberose bulbs for gamma rays when @ 2 kR and the LC50 for EMS@60-70 mM and DES@ 25 mM, respectively. Estrada-Basaldua et al. (2011) reported that the LD50 of the plants grown from acclimated shoots (9.09 Gy) was lower than the LD50 of plants grown from tubers established in vivo (25.91 Gy). The radiation dose of 30 Gy was lethal for the plants grown from tubers established in vivo. Pohare et al. (2012) examined the sensitivity test of Polianthes tuberose L. 
to ultraviolet radiations. UV radiations treatments showed slight differences in the morphological characters as compared to the control. However, marked differences in the morphological characters were observed with a UV radiation dose of 25 minutes. In another study, Pohare et al. (2013) used gamma viz. 10, 20, 30, 40 and 50 Gy rays to treated in vitro plantlets and assessed the sensitivity of in vitro plantlets. Lower doses of gamma rays did not show any response but marked differences in the morphological characters observed with a gamma radiation dose of 30 Gy. Singh et al. (2015) studied the effect of EMS (0.25 and 1.0\%) in three prominent tuberose cultivars like Calcutta double, Prajwal and Shringar. Among the cultivars, Calcutta double appeared to be more sensitive to EMS than Prajwal and Shringar. Kayalvizhi et al. (2016) determined the sensitivity test with the help of probit analysis based on their survival percentage during the treatment period. Probit analysis revealed the LD50 value for gamma rays was $(2.13 \mathrm{kR})$ while the LC50 values for EMS and DES were fixed as, $62.92 \mathrm{mM}$ and $21.65 \mathrm{mM}$, respectively. However, in another experiment, Kayalvizhi et al. (2016 a) reported the LC50 value was fixed for DES $25 \mathrm{mM}$ and EMS 60 $\mathrm{mM}$, respectively. Sah et al. (2017) reported that Sikkim Selection showed $100 \%$ sprouting with $2.0 \mathrm{kR}$ gamma rays rest of the thirteen genotypes decreased the percentage of sprouting. Sharavani et al. (2019) standardized the lethal dose of gamma rays in tuberose based on probit curve and mortality percentage analysis. The probit analysis exhibited that bulbs treated with LD50 value of gamma irradiation for tuberose var. Hyderabad Single was 20 Gy gamma rays. Kutty et al. (2020) analyzed the radiation sensitivity test to know the lethal dose of $\gamma$-radiation (LD50) based on survival \% of irradiated tuberose plants with appropriate controls after 30 days of the plantation. The lethal dose at which $50 \%$ (LD50) of the tubers survived was found to be $9.64 \mathrm{~Gy}$.

\section{Optimal treatment dose}

Krishnan et al. (2003) reported that gamma rays at 15 Gy and 20 Gy and EMS at 1.0 and 2.0 percent induced morphological variants like chlorophyll mutants, branched flower stalk mutants, compact inflorescence mutants, and nonflowering mutants. Singh et al. (2011) found that treatment, 1, 2 and
$3 \mathrm{kr}$ showed mutagenic effect in $\mathrm{V}_{1} \mathrm{M}_{1}$ and $\mathrm{V}_{2} \mathrm{M}_{2}$ generation of tuberose while 4 and $5 \mathrm{kr}$ exhibited lethal effect. Pohare et al. (2013) optimized 30 Gy rays to changes in plant height, several leaves, leaf size and color under in vitro conditions as compared to the control plant. Kainthura and Srivastava (2015) exposed the bulb of to gamma rays with $1 \mathrm{Kr}$ and $1.5 \mathrm{Kr}$, x-rays @ $0.6 \mathrm{Kr}$ and $1.2 \mathrm{Kr}$ and EMS @ 0.1\% and 0.2\% and untreated as a control. Lower doses had a significant stimulative effect on sprouting percentage, days took to sprouting. In contrast, most of the parameters showed a decrease from desired levels i.e., survival rate, leaf length, number of spikes/plant \& florets/spike, flowering duration, and vase life. However, EMS $0.2 \%$ and 1.2 $\mathrm{Kr} \mathrm{x}$-rays resulted in changes in flowering aspects of tuberose. Singh et al. (2015) optimized higher doses (1\%) of EMS than the lower dose $0.25 \%$ EMS to changes in various growth and flowering traits in tuberose. Kainthura et al. (2016) reported that lower doses of mutagens (gamma rays, $x$ rays and EMS) had significant stimulative effect on vegetative parameters viz., sprouting percentage, days to sprouting, while the parameters like survival rate, leaf length, number of spikes per plant, florets per spike, flowering duration and vase life while higher doses of all mutagens had detrimental effects on the vegetative and floral characters. Kayalvizhi et al. (2016) exposed the bulbs of tuberose cultivar Prajwal to gamma-ray (0.5, 1.0, 1.5, 2.0, 2.5, $3.0 \mathrm{kR})$ and soaking treatment was done in Ethyl Methane Sulphonate (EMS) $(15,30,45,60,75$ and $90 \mathrm{mM})$ and Diethyl Sulphate (DES) $(10,15,20,25,30$ and $35 \mathrm{mM}$ ) respectively. Gamma-ray treated bulbs showed lower sprouting and survival percentages and very slow growth during the crop period. Abnormal reduction was observed in the survival of bulbs; decreasing the survival percentage, plant height and number of leaves were observed with increase in concentrations of EMS and DES. Higher concentrations of gamma rays 2.5 to $3.0 \mathrm{kR}$, EMS 70-95 mM and DES 30-35 mM lead to bulbs' death. Kayalvizhi et al. (2016a) optimized lower doses of (15 mM of DES and $30 \mathrm{mM}$ of EMS) for created variations in floral characters variable except for control. Kayalvizhi et al. (2017) induced chlorophyll mutants viz. 'albino' 'chlorina' ‘striata' while 'xantha' with $1.0 \mathrm{kR}$ gamma rays while broadleaf mutants were observed with $15 \mathrm{mM}$ DES. Maximum branched leaf mutants were produced $1.0 \mathrm{kR}$ and 
$2.0 \mathrm{kR}$ gamma rays. A non flowering spike plant was obtained with $25 \mathrm{mM}$ DES while eleven tepal florets induced by $15 \mathrm{mM}$ DES doses, but control plants had only six tepal florets. Kayalvizhi et al. (2017a) noted that gamma rays, EMS, and DES-treated population had manifested reduced expression than the control (untreated population) for most of the morphological and floral characters. Sah et al. (2017) optimized $2 \mathrm{kR}$ doses of gamma rays to induce maximum mutants while $4 \mathrm{kR}$ doses of gamma rays proved to be a lethal dose. Kainthura et al. (2018) observed that lower doses of EMS $(0.1 \%)$ resulted in an increase in floral size of few florets within a spike. Yadav et al. (2018) optimized that lower concentration of EMS (0.25\%) emerged earlier sprouting, complete sprouting, days to spike emergence but at higher doses delayed the initiation of all parameters. The lower doses (0.25\% EMS) also increased plant height, a number of leaves, decreased length of leaves, while higher doses increased length of leaves and reduced number of leaves and plant height. Among the duration time of dipping, 8 hours was found effective in increasing plant height, number of leaves and reduce length of leaves. The interaction effect was found highest in treatment combination $0.25 \%$ EMS with 8 hours dipping duration for growth parameters. Jyoti et al. (2019) observed more number of mutants from freshly harvested bulbs in cultivars of Prajwal and Phule Rajani when irradiated with 7.5 Gy and 10.0 Gy gamma rays. Sharavani et al. (2019) noted that bulbs treated with 10 and 15 Gy showed narrowshaped flowers while 20 Gy demonstrated tubular flower shape. However, 5 Gy doses of gamma rays produced maximum plant height, number of leaves, leaf width, and number of tillers. Increasing the dose of gamma rays from $10 \mathrm{~Gy}$, there was a significant reduction in vegetative growth in tuberose white, variegated leaves and albino mutants were recorded with bulbs treated by 20Gy gamma rays. Singh and Sadhukhan (2019) recorded that among the physical mutagens, 10 and 20 Gy gamma rays were optimized for inducing of mutants. In chemical mutagens, EMS 1\% was found superior in terms of induction of mutants as compared to 0.25 and $0.5 \%$. Kutty et al. (2020) observed that a higher dose of mutagen decreased in plants sprouted from tubers. The growth pattern of plants sprouted from irradiated tubers and control also correlated with the chlorophyll content. The tubers exposed to the lower dose (10 Gy) showed enhanced growth rate, higher floral volatile content in comparison with control plants. However, plants sprouted from tubers exposed to a higher dose of radiation showed lethal effects.

\section{Oxygen enhancement ratio}

Oxygen enhancement ratio is also affected mutation efficiency in plants. It ratio can enhance the mutagen frequency when the experimental conditions may be supplemented with oxygen (e.g., bubbling oxygen through the mutagen solution in the case of chemical mutagenesis). However, such enhancement is undesirable; an oxygen-free environment should be used to get desirable results. The effect of oxygen on mutagenesis depends on the tissue's moisture contentdepends on the tissue's moisture content and higher the tissue moisture, decreasing the tissue oxygen supply. Types of mutagens vary in the importance of moisture in their effectiveness for inducing mutation, such as X-rays is more affected by moisture content than gamma rays.

\section{Temperature and treatment time}

In chemical mutagenesis, the temperature can affect the mutagen efficiency, and higher temperature accelerates the reactions. Kayalvizhi et al. (2016, 2016 a) reported the temperature $\left(25 \pm 2^{\circ} \mathrm{C}\right)$ for the chemical mutagens; then the bulbs were soaked in EMS with 8 hours treatments. Under the treatments of DES, the bulbs were soaked in an aqueous solution for 8 hours. The solution was changed every 45 minutes with a freshly prepared solution for the effectiveness of DES, which will persist. Singh and Sadhukhan (2019) treated the seeds of tuberose with EMS at $\pm 25^{\circ} \mathrm{C}$, and dipping time was optimized for $4 \mathrm{~h}$.

\section{$\mathrm{pH}$}

During chemical mutagenesis, $\mathrm{pH}$ plays an important role in successful mutagenesis in plants. For example, EMS is most effective at pH 7.0, whereas sodium azide induces the best mutagenesis at $\mathrm{pH}$ 3.0. Kayalvizhi et al. $(2016,2016 a)$ maintained the $\mathrm{pH}$ of the solution at 7.0 by using phosphate buffer for induction of mutation in tuberose with EMS. 


\section{Selection of mutants}

Patil et al. (1975) obtained one mutant with a bolder flower at $0.5 \mathrm{Kr}$ dose of gamma rays as compared to control. Krishnan et al. (2003) isolated nine mutants' viz., dwarf mutants, high tiller mutants, nontillering mutants, compact inflorescence mutants, tall mutants, longleaf mutants, broadleaf mutants, large flower mutants, and giant inflorescence mutants with gamma rays and EMS. All mutants retained the characters in $\mathrm{VM}_{2}$ generation. Pohare et al. (2012) isolated pale green plantlets when in vitro plantlets were treated with UV rays at $2 \mathrm{~m}$ minutes. UV rays produced pale yellow leaves, but non-treated plantlets had dark green leaves. UV rays treated plantlets increased plant height, leaf length, and leaf width but decreased the number of leaves. Kainthura and Srivastava (2015) also isolated six mutants by employing of gamma rays, $x$-rays, and EMS in four varieties of tuberose. Navabi et al. (2016) noted changes in plant morphology by gamma rays, but no changes were observed in flower color. Kayalvizhi et al. (2017) induced chlorophyll mutants viz. 'albino' 'chlorina' 'striata' and 'xantha' in $\mathrm{M}_{1} \mathrm{~V}_{2}$ generation with gamma rays. $15 \mathrm{mM}$ DES induced broad leaf mutants while branched leaf mutants were produced by $1.0 \mathrm{kR}$ and $2.0 \mathrm{kR}$ gamma rays. A non flowering spike mutant was induced by 25 mM DES. In contrast, eleven tepal florets mutant recorded with15 mM DES but had only six tepal florets in control plants. Sah et al. (2017) treated fourteen cultivars of tuberose by gamma rays. Mutant GKTC-4 had more length of floret and maximum duration of flowering as compared to control. Mutant Sikkim Selection showed a maximum number of bulbs/hill, higher bulb weight and more diameter of bulb asbulb weight, and more bulb diameter than control. Jyothi et al. (2019) induced a mutant with a longer spike and more florets in cultivar Prajwal while dwarf mutant was derived from cv. Phule Rajani with 7.5 Gy gamma rays under $M_{1} V_{1}$ generation. Prajwal cultivar bulbs uprooted after six weeks from soil and treated by 7.5 Gy doses had two spike heads that were fused from the neck. 7.5 Gy gamma irradiation at freshly harvested bulb produced flower color mutant in cv. Prajwal with slightly pinkish color flowers. The population derived from vM1 generation further grown for vM2 generation to examine the variations in mutants. Bulbs of cultivar Prajwal took at six weeks after uprooting stage and treated with 10.0 Gy induced two flower mutants including one of changing the shape of the petal from elongated to round shape and another floret of the spike showed the same petal shape. Bulbs collected from three weeks after uprooting of crop and treated with 2.5 Gy of gamma rays resulted in a mutant with change in flower shape and increased petal length and with big florets than the normal floret of cv. Prajwal. Another mutant was derived from the cv. Phule Rajani, when freshly harvested bulbs were treated with 7.5 Gy gamma irradiation dose. The spike was longer $(94 \mathrm{~cm})$ than the normal spike length $(70-74$ $\mathrm{cm}$ ) in general. This mutant was the same as that one that was observed in vM1 generation. This was derived from the same plot at 7.5 Gy gamma irradiation dose in cv. Prajwal from the freshly harvested bulb. Other mutant with individual floret become small and arranged at equal space intervals produced by cv. Prajwal from the freshly harvested bulb when treated with 7.5 Gy gamma rays. However, another mutant derived from cv. Phule Rajani form freshly harvested bulb at 10.0 Gy gamma irradiation dose. Mutant showed a white color band formed at the middle of the leaf. All the leaves that emerged from the bulb were showed the same pattern. Sharavani et al. (2019) isolated a narrow-shaped flower mutant when bulbs were irradiated with 10 and 15 Gy gamma rays, while 20 Gy demonstrated tubular flower shape. Sharavani et al. (2019) obtained variegated leaves and albino mutants by bulbs treated with 20Gy. Singh and Sadhukhan ( 2019) isolated variegated leaf mutant with 20 Gy gamma rays by treating bulbs of Calcutta Double while branched mutant and tall mutant induced by 10 Gy gamma-rays in the same cultivar. However, dwarf mutant flower mutant (reduced in petal) was obtained from the seeds of cultivar Suvasini when treated with 1\% EMS. Kutty et al. (2020) noted that tubers irradiated with 10 Gy doses of $\gamma$-rays emerged earlier flowering and plants induced with higher doses, i.e., $20 \mathrm{~Gy}$ and 25 Gy took a longer time to flower. Plants treated with 25 Gy gamma rays produced shorter spike; however, 10 Gy and 15 Gy irradiated plants sometimes displayed seven tepals against control flowers where the number is usually six. A higher number of new tubers was observed with $10 \mathrm{~Gy}$ of gamma rays, while other doses such as $15 \mathrm{~Gy}, 20$ Gy, and 25 Gy displayed fewer new tubers. Emitted 
volatiles in flowers increased with a dose of $10 \mathrm{~Gy}$ in both $M V_{1}$ and $M V_{2}$ generation compared to emitted floral scents from control plants. In MV2 generation, 10 Gy irradiation doses showed an enhancement in volatiles emission.

\section{CONCLUSION}

It has been observed from the various studies that the continuous implications of traditional breeding in flowering crops cause the narrowing of the gene pool where cultivars are drawn, hence hampering future progress in flowers. However, mutation breeding has been extensively used to promote a novel cultivar in flowering crops. Mutation breeding has the potential role of developing new varieties that require less time for establishments in different locations. Sometimes conventional breeding can be very challenging given its propagation mode; thus, physical and chemical mutagens could be a potential tool to resolve thisbreeding-related obstacle. Various research reports suggested that a lower amount of mutagens produces positive and effective influences on vegetative, flowering, and physico-chemical characteristics in various kinds of tuberose plants; however, higher doses of these mutagens have a deleterious effects on plants with some exceptions. Various workers have also mentioned that optimum doses of physical and chemical mutagens varied from the specific crop and genotypes.

\section{Future prospectives}

The conventional breeding method takes several years to develop a new cultivar/variety from available germplasm and wild species. However, mutation breeding approaches have been proved a potential tool to improve quantitative and quantitative traits in flowering crops. Improvement through in vitro culture selection procedures such as microspore culture, anther culture, cell suspension, regeneration of haploid, diploid, tetraploid, and doubled haploid plants and chromosome doubling can be achieved with integrated molecular mutation breeding (Raina et al. 2016; Schwarzacher 1994). Plant transformation methods and gene silencing technology can effectively evaluate and authenticate newly discovered endogenous genes with their functions in plants. Such desirable genes may be used to develop genetically manipulated plants that have good quality and higher productivity of flowers (Dandekar 2003). Polyploidy plays a vital role in the development of new ornamental varieties with desirable morphological and flowering traits such as plant size and vigor, leaf thickness, more prominent flowers with thicker petals, intense color of leaves and flowers, long-lasting flowers, compactness, the fragrance of flowers, dwarfness and restored fertility. In general, polyploidy may occur naturally due to the formation of unreduced gametes or can also be induced artificially by doubling the number of chromosomes in somatic cells. In ornamental plants, natural polyploid plants are unavailable, so polyploidy is induced with the help of mitotic inhibitor chemicals. In recent days, colchicine has been widely used as a mitotic inhibitor for the induction of polyploidy in plants where cell division is inhibited by chromosome segregation. Different planting materials like seeds, apical meristems, bulbs, corms, rhizomes, flower buds, roots etc., can be used to induce polyploidy through various methods such as dipping/soaking dropping, or cotton wool.

Mutations in flowering crops can be induced by several methods such as physical, chemical, and insertional mutagen treatments; however, these methods are not commonly used by flower breeders due to not being easily readily available, more expensive, and tedious process in plant materials treatment. In recent days, mutations in flowering crops are being identified with the help of advanced applications of next-generation sequencing (NGS) techniques, where millions of mutations are detected in a concise period, therefore, considered convenient and cost-efficient tools for flower breeders. Mutation breeding integrated with whole-genome sequencing has provided a robust platform for forward and reverse genetic applications in floricultural crops where the availability of whole-genome sequence information for a large number of crops has enabled target-specific genome editing techniques as a preferable method to engineer desired mutations. The available genome editing approaches such as ZFNs (Zinc Finger Nucleases), transcription activator-like effector nucleases (TALENS), and clustered regularly interspaced short palindromic repeats (CRISPR)/CRISPR-associated9 (Cas9) endonuclease can be utilized to perform site-specific mutations in several ornamental plants. Among the genome editing techniques, CRISPR/Cas9 has been 
proved very effective in genome editing because of its simplicity and robustness. Therefore, CRISPR/ Cas9 has been utilized to enhance biotic and abiotic stress resistance in plants.

\section{REFERENCES}

Abhangrao, A.K. 2019. Studies on mutation breeding in tuberose (Polianthes tuberosa linn.). Doctoral dissertation, Vasantrao Naik Marathwada Krishi Vidyapeeth, Parbhani).

Abraham, V. and Desai, B.M. 1976a. Biological effectiveness of fast neutrons and gamma rays in some bulbous ornamentals. Indian J. Genet. Plant Breed, 36(2): 230-237.

Abraham, V. and Desai, B.M. 1976b. Radiation induced mutants in tuberose. Indian J. Genet. Plant Breed, 36(3): 328-331.

Ahmad, I., Ahmad, T., Asif, M., Saleem, M. and Akram, A. 2009. Effect of bulb size on growth, flowering and bulbils production of tuberose. Sarhad J. Agric., 25(3): 391-398.

Ali, J. 2002. Effect of gamma irradiation on vegetative and floral characteristics of tuberose corms (Polianthes tuberosa L.) var. Single. Faisalabad (Pakistan), UAF, pp. 90.

Anonymous. 1981. The Tuberose out all winter. The garden London 20: 25.

Ayangar, R.K. 1963. Cytological basis of sterility is Polianthes tuberosa Linn. Proc. $50^{\text {th }}$ Indian Sci. cong. Part III section 6 (Bot.) Abst. No. 247: 444-445.

Barba-Gonzalez, R., Rodriguez-Dominguez, J.M., CastanedaSaucedo, Ma. C., Rodriguez, A., Van Tuyl, J. M. and Tapia-Caampos, E. 2012. Mexican genotypes I. The genus Polianthes. Floric Ornament Biotechnol., 6: 122-128.

Barba-Gonzalez, R., Rodríguez-Domínguez, J. M., CruzCruz, A. de. la., Lara-Bañuelos, T.Y., Tapia-Campos, E. and Castañeda- Saucedo, M.C. 2014. Polianthes breeding. AGRIS Since, 1000: 505-510.

Bharathi, T.U. and Kirthishree, S.P. 2019. Hybridization and evaluation of hybrids in tuberose (Polianthes tuberosa L.). Int. J. Chem. Stud., 7(1): 189-193.

Bindhani, B.K., Dalal, A.K. and Behara, B. 2004. Role of auxins for callus induction and chromosomal variation in Polianthes tuberosa L. 'Single'. Indian J. Genet. Plant Breed, 64(2): 173-174.

Bundrant, L.A. 1985. Polianthes tuberose and its hybrids. Herbertia, pp. 55-60.

Chandravadana, M.V., Srinivas, M. and Murthy, N. 1994. Indole in tuberose (Polianthes tuberosa) varieties. J Essent Oil Res., 6(6): 653-655

Chase, M.W., Christenhusz, M.J.M., Fay, M.F., Byng, J.W., Judd, W.S., Soltis, D.E., Mebberley, D.J., Sennikov, A.N., Soltis, P.S.and Stevens, P.F. 2016. An update of the angiosperm phylogeny group classification for the orders and families of flowering plants: APG IV. Bot. J. Linn. Soc., 181(1): 1-20.
Dandekar, A.M. 2003. Techniques for manipulating quality and productivity traits in horticultural crops. Acta Hortic., 625: 293-305.

Datta, S.K. 2017. Breeding of ornamentals tuberose (Polianthes tuberosa L.). Curr Sci., 7: 113.

Datta, S.K. 1993. Possibilities of directive mutation in ornamentals. Toward enhanced and sustainable agricultural productivity in the 2000's: breeding research and biotechnology. Proceeding of SABRAO seventh international congress and WSAA symposium, 1(35): 313-316.

Datta, S.K. and Shukla, R. 1996. Effect of gamma irradiation on mutants of tuberose (Polianthes tuberose L). Herberita, 59: 139-141.

Datta, S.K. and Banerji, B.K. 1995. Cytogenetical studies in ornamental plants. In: Adv Hortic, 12(1): 267-334.

Datta, S.K. 2014. Induced mutagenesis: basic knowledge for technological success. National Botanical Research Institute, India, pp. 97-140.

Estrada-Basaldua, J., Pedraza-Santos, M., De La Cruz Torres, E., Martínez-Palacios, A., Saenz-Romero, C. and MoralesGarcía, J. 2011. Effect of 60Co gamma rays in tuberose (Polianthes tuberosa L.). Revista Mexicana de Ciencias Agricolas, 2: 445-458.

González-Gutiérrez, A.G. and Rodríguez-Garay, B. 2016. Embryogenesis in Polianthes tuberosa L var. simple: from megasporogenesis to early embryo development. Springer Plu., 5: 1804

Guo, W., Wen-Wen, W. and Yan, X. 2009. Mutagenic effects of Co-gamma rays on Polianthes tuberosa L. J. Nuclear Agric. Sci., 23: 799-804.

Gupta, M.N., Sumiran R. and Shukla, R. 1974. Mutation breeding of tuberose (Polianthes tuberosa L.). In : Symposium, Use of radiations and radioisotopes in studies of plant productivity, Pantnagar, pp. 169-179.

Gupta, M.N., Laxmi, V. and Datta, S.K. 1984. Cytomorphological studies on control and gamma induced mutants of tuberose. J. Nuclear Agric. Biol., 13(4): 140-141.

Hemanta, L. 2015. Studies on floral biology, pollination and crossability in tuberose (Polianthes tuberosa L.). PhD. Thesis, GB Pant Univ. Agri. Technol., Pantnagar, India.

Howard, T.M. 1977. Polianthes X Blissii Worsley, Plant Life, pp. 82-84.

Howard, T.M. 1978. Polianthes Hybrids. Plant Life, pp. 126129.

Howard, T.M. 1985. Mexican field crop 1984. Stalking the Polianthes of Mexico, Part one. Herbertia, 41: 98-117.

Howard, T.M. 1986. Stalking the Polianthes of Mexico-Part two. Herbertia, pp. 84-87.

Huang, K.L., Miyajima, I., Okubo, H., Shen, T.M. and Huang, T.S. 2001. Flower colours and pigments in hybrid tuberose (Polianthes). Sci. Hortic., 88(3): 235-241.

Huang, K.L., Miyajima, I., Okubo, H., Shen, T.M. and T.S. Huang. 2002. Breeding of colored tuberose (Polianthes) and cultural experiments in Taiwan. Acta Hortic., 570: 367 -371. 
Jayasree, P.L., Srinivas, M. and Krishnan R. 2001. Cytological studies in tuberose varieties. Nucleus, 44: 196-201.

Joshi, A.C. and Pantulu, J.V. 1941. A morphological and cytological study of Polianthes tuberosa Linn. J. Indian Bot. Soc., 20: 37-69.

Jyothi, R., Singh, K.P., Mohapatra, T. and Kumar, N.K. 2019. Induction of novel mutants and their stability using gamma irradiation in tuberose (Polianthes tuberosa L). Int. J. Curr. Microbiol. App. Sci., 8(8): 1815-1824.

Kainthuar, P. and Srivastava, R. 2015 Induction of genetic variability and isolation of mutants in tuberose (Polianthes tuberosa L). Trop. Agric. Res., 26(4): 721-732.

Kaintura, P., Srivastava, R and Kapoor, M. 2016. Effect of physical and chemical mutagens on different cultivars of tuberose (Polianthes tuberosa Linn.) with particular reference to induction of genetic variability. Int. J. Agric. Sci., 8(15): 1257-1260.

Kaintura, P., Gupta, Y and Gaur, G. 2018. Morphological variation in floral charcters on tuberose (Polianthes tuberosa Linn.) cultivars treated with EMS. Plantica., 2(1): 112 - 115.

Karihaloo, J.L. 2019. Cytological and hybridization studies in three cultivars of tuberose (Polianthes tuberosa L.). Cytologia, 84(1): 47-52.

Kayalvizhi, K., Kannan, M. and Ganga, M. 2016. Effects of gamma irradiation and chemical mutagens in tuberose Polianthes tuberosa L. Res. Environ. Life Sci., 9(8): 1030-1032.

Kayalvizhi, K., Kannan, M. and Ganga, M. 2016a Mutagenic effects of chemical mutagens on tuberose (Polianthes tuberosa L.) var. Prajwal. J. Inno. Agri., 3(2): 11-13.

Kayalvizhi, K., Kannan, M. and Ganga, M. 2017. Effect of physical and chemical mutagens on morphological characters in M1V2 generation of tuberose (Polianthes tuberosa L.). Int. J. Curr. Microbiol. Appl. Sci., 6(4): 2492-2499.

Kayalvizhi, K., Kannan, M. and Ganga, M. 2017a. Effect of mutagens on vegetative and floral characters in M1V2 generation of tuberose (Polianthes tuberosa L.). Bull. Env. Pharmacol. Life Sci., 6(1): 422-429.

Kniphof, J.H. 1964. Botanica in Originali seu Herbarium Vivum, Halle.

Krasaechai, A. 1992. Effect of gamma radiation on tuberose (Polyanthes tuberosa). Kasetsart J. Nat. Sci., 26(1): 6-11.

Krishnamoorthy, V. 2014. Assessment of tuberose (Polianthes tuberosa L.) varieties for growth and yield characters. Asian J. Hortic., 9(2): 515-517.

Krishnamurthy, K.B. and Srinivas, M. 2005. Histological and histo-chemical studies of ovule development in tuberose (Polianthes tuberosa Linn.). J. Ornam. Hortic., 8(2): 81-85.

Krishnan, A.G., Geetha, C.K., Rajeevan, P.K., Valsalakumari, P.K. and Saifudeen, N. 2003. Induced mutation in tuberose (Polianthes tuberosa Linn.) by gamma rays. In Proceedings of the National Symposium on Recent Advances in Indian Floriculture, Kerala Agricultural University Trichur, pp. 255-261.

Kutty, N.N., Ghissing, U., Kumar, M., Maiti, M.K. and Mitra, A. 2020. Intense floral scent emission in Polianthes tuberosa
L. variants sprouted from $\gamma$-irradiated tubers. J. Plant Growth Regul., 39(1): 112-121.

LaMarck, J.B.A.P. de. 1797. Illustration des Genres, vol .2, Paris.

Laxmi, V., Gupta, M.N. and Datta, S.K. 1984. Cytological studies on control and gamma induced mutants of tuberose. J. Nuclear Agri. E Biol., 13: 140-141.

Lin, T.S. and Shen, T.M. 2004. Study on karyotype of Polianthes tuberosa L. J. Agric. For. NCYU, 1: 1-12.

Misra, R.L. and Mahesh, K.S. 1995. Bulbous ornamental breeding. In: Advances in Horticulture Ornamental Plants, Malhotra Publishing House, New Delhi, 12: 475494.

Naik, B.C., Kamble, B.S., Tirakannanavar, S. and Parit, S. 2018. Evaluation of different genotypes of tuberose (Polianthes tuberosa L.) for growth, flowering and yield characters. Int. J. Curr. Microbiol. App. Sci., 7(7): 4135-4141.

Navabi, Y., Norouzi, M., Arab, M. and Daylami, S.D. 2016. Mutagenesis via exposure to gamma-rays in tuberose (Polianthes tuberosa). Electron J. Biol., 12(2): 168-172.

Oladosu, Y., Rafii, M.Y., Abdullah, N., Hussin, G., Ramli, A., Rahim, H.A., Miah, G., and Usman, M. 2016. Principle and application of plant mutagenesis in crop improvement: A review. Biotechnol. Biotechnol. Equip., 30(1): 1-16.

Panigrahi, J. and Saiyad, M.S.L. 2013. In vitro propagation of Polianthes tuberosa L. cultivars (Calcutta Single). Int. J. Plant Animal Environ. Sci., 3: 76-79.

Patil, A.V., Kale, P.N. and Kaulgud, S.N. 1975. Some observations of gamma irradiation on growth and flowering of tuberose bulbs. Curr. Sci., 44: 406-07.

Patil, S.D. and Patil, H.E. 2009. Improvement of major ornamental crops through mutation breeding. Int. J. Agric. Sci., 5(2): 628-632.

Pohare, M., Batule, B., Bhor, S., Shahakar, S.B., Kelatkar, S.K. and Varandani, S. 2013. Effect of gamma radiations on the morphological characters in in vitro regenerated Polianthes tuberosa. Indian Hortic. J., 3: 95-97.

Pohare, M., Rathod, H.P., Shahakar, S.B., Kelatkar, S.K. and Suryawanshi, P. 2012. Effects of UV radiations on morphological characters in in vitro regenerated Polianthes tuberosa. Res. J. Agric. Sci., 3: 1307-1308.

Pooja, K. 2016. Effect of physical and chemical mutagens on different cultivars of tuberose (Polianthes tuberosa Linn.) with particular reference to induction of genetic variability. Int. J. Agric. Sci., 0975-3710.

Raina, A, Laskar, R.A., Khursheed, S., Amin, R., Tantray, Y.R., Parveen, K. and Khan, S. 2016. Role of mutation breeding in crop improvement-past, present, and future. Asian Res. J. Agr., 2: 1-13.

Raja, K. and Palanisamy, V. 1999. Effect of bulb size on growth, flowering and bulb yield in tuberose (Polianthes tuberosa L.) cv. "Single". South Indian Hort., 47: 322-324.

Raja, K., Palanisamy, V. and Selveraju, P. 2003. Evolving sexual seed propagation in tuberose (Polianthes tuberosa L.) cv.Single'. Progress Hortic., 35(2): 233-233. 
Rammamurthy, S., Venkataraman, S., Meera, R., Prasad, S., Chriristina, A.J.M. and Devi, P. 2010. Phytochemical investigation of Polianthes tuberosa. Int. J. Pharm. Tech. Res., 2: 1204-1206.

Roa, D.V.R., Reddy, K.B., Naidu, L.N. and Suryanarayana, V. 1991. Effect of bulb size and depth of planting on growth and flowering of tuberose (Polianthes tuberosa L.) cv. Single. Hortic Sci, 39(3): 143-145.

Rosalind, L., Usha Bharathi, T., Kulkarni, B.S., Dhanajaya, M.V., Nair, S.A. and Munikrishnappa, P.M. 2018. Studies on seed germination and seedling evaluation of tuberose (Polianthes tuberosa L.) hybrids. J. Pharmacogn. Phytochem., 7(6): 23-25

Rumph, E.G.1797. Herbarium Amboinense, vol.5, Amsterdam.

Sah, R., Singh, A.K., Sisodia, A. and Padhi, M. 2017. Influence of gamma dose on growth, flower and bulb parameters in tuberose varieties. Int. J. Curr. Microbiol. App. Sci., 6(8): 2038-2043.

Salisburi, R.A. 1812. On the cultivation of the Polianthes tuberosa, or tuberose. Trans. Hort. Soc., London 1: 41-53.

Sambandhamurthi, S. 1983. Studies on induced mutations in tuberose (Polianthes tuberosa L.). Ph.D. Thesis submitted to Tamil Nadu Agricultural University, Coimbatore.

Sathyanarayana Reddy. B., Singh, K. and Gangadharappa, P.M. 1998. Effect of bulb size on growth of tuberose cv. Double. Karnataka J. Agric. Sci., 11(1): 287-289.

Satô, D. 1938. Karyotype alteration and phylogeny. Cytologia, 4(9): 203-242.

Schira, T. and Lanteri, S. 1986. Cytological observations on two cultivars of Polianthes tuberosa, Anmali dell' Institute Sperimantale per le Floriculture, 14: 1-18.

Schiva, T. and Lanteri, S. 1983. Osservazioni citologiche sue due cultivar di Polianthes tuberosa. Ann. Ist. Sper. Floric., 14(1): $1-18$

Schiva, T. and Lanteri, S. 1984. Caryological differences between cultivars of Polianthes tuberosa L. Genetica Agraria. 38(3): 347.

Schwarzacher, T. and Leitch, A.R. 1994. Enzymatic treatment of plant material to spread chromosomes for in situ hybridization. In Protocols for Nucleic Acid Analysis by Nonradioactive Probes, pp. 153-160.

Sharavani, C.S.R., Kode, S.L., Priya, T, Bharti, T.U, Sekhar, M.R., Ruth, C. and Ramakrishna, M. 2019. Studies on effect of gamma irradiation on survival and growth of tuberose (Polianthes tuberosa L.). Adv. Biores., 10(1): 109-113.

Sharma, A.K. and Ghosh, C. 1956. The cytology of two varieties of Polyanthes tuberosa with special reference to their inter-relationship and sterility. Genetica, 28: 99-111.

Shen, T.M., Huang, K.L. and Huang, T.S. 1987. Study of tuberose hybridization. Acta Hortic., 205: 71-74.

Shen, T.M., Huang, K.L., Shen, R.S. and Du, B.S. 1997. Breeding for new flower colors in Polianthus tuberose. J. Chinese Soc. Hortic. Sci., 43: 358-367.

Shen, T.M., Huang, K.L., Shen, R.S. and Du, B.S. 2003. Breeding of dwarf tuberose (Polianthes tuberosa L.). Acta Hortic., 624: 73-76.
Shinners, L.H. 1966. Texas Polianthes, including Manfreda (Agave subgenus Manfreda and Runyonia (Agavaceae) SIDA, 2(4): 333-338.

Shukla, R. and Datta, S.K. 1993. Gamma irradiation studies on Polianthes tuberosa L. J. Ornam. Hortic., 1(2): 36-41.

Singh, K.P. and Singh, M.C. 2013a. Evaluation of Double petalled cultivars of tuberose (Polianthes tuberosa L.) under Delhi condition. Asian J. Hort., 8(2): 512-514.

Singh, P.K., Sadhukhan, R., Dudhane, A.S., Kumar, V. and Sarkar, H.K. 2015. Preliminary study on mutagenic effect of EMS on tuberose (Polianthes tuberosa L.). Environ. Ecol., 33(3A): 1386-1390.

Singh, P.K. and Sadhukhan, R. 2019. Identification of variants induced by physical and chemical mutagens in tuberose (Polianthes tuberosa L.). J. Crop Weed, 15(2): 40-45.

Singh, P.K., Sadhukhan R., Sarkar H.K. and Roy, K. 2013b. Effect of EMS on morpho-anatomical changes in tuberose (Polianthes tuberose L.). Floric Ornam Biotechnol., 7: 103-105.

Singh, R., Goyal, R.K and Godra, N.R. 2011. Effect of gamma irradiation on growth, flowering and bulbs production in tuberose (Polianthes tuberosa L.) cv. Double. Haryana J. Hortic. Sci., 40 (3 \& 4): 128-130.

Sreethramu, G.K., Bhat, R.N. and Ranjanna., K.M. 2000. Studies on pollen viability, pollen germination and seed germination in tuberose hybrids and cultivars. South Ind. Hortic, 48(1): 78-82.

Srinivas, M., Murthy, N. and Karihaloo, J. L. 1995. Tuberose hybrids Shringar and Suvasini. Ind. Hortic., 40: 5-7.

Traub, H.P. 1953. Polianthes tuberose. Plant Life, 9: 140.

Ullrich, 1993. Early illustrations of Polianthes tuberosa L. (Agavaceae). Herbertia, 49(1\&2): 50-57.

Uma, S. and Gowda, J.V.N. 1999. Self-incompatibility studies in Polianthes tuberosa L. Crop Res. Hisar, 18(3): 450-453.

Verhock- Williams, S.E. 1975. A study of the Tribe Polianthes theae (including Manfreda) and Revision of Manfreda and Prochnyanthes (Agavaceae). University Microfilms International No. 75-17326, Ann Arbor.

Vij, S.P., Sharma, M. and Chaudhary, J.D. 1982. Cytogenetical investigation into some garden ornamentals III. Chromosomes in some monocot taxa. Cytologia, 47: 649-663.

Wani, M.R, Kozgar, M.I. and Tomlekova, N. 2014. Mutation breeding: A novel technique for genetic improvement of pulse crops particularly Chickpea (Cicer arietinum L.). Springer, pp. 217-248.

Watkins, G.M. 1936. Chromosome numbers and species characters. American J. Bot., 23: 328- 333.

Westland, A. 1881. Opium Traffic. British Medical J., 2(1070): 30.

Whitaker, T.W. 1934. Chromosome constitution in certain monocotyledons. J. Arnold Arbor, 15(2): 135-143.

Woods, D.R. 1881. Successful Floriculture. New Brighton,. USA

Worsley, A. 1911. The genus Polianthes. J. Royal including Peochyanthes Hort. Soc. London, 36(3): 603-605. 
Yadav, G., Sheoran, V., Kumar, S., Kaur, M., Kumar, S., Beniwal, B. and Sourabh, V. 2018. Effect of mutagen ethyl methane sulfonate on growth characters of tuberose (Polianthes tuberosa L.) cv. Prajwal. Int. J. Chem. Sci., 7: 412-416.

Younis, A. and Abraham, V. 1975. Biological effectiveness of fast neutrons and gamma rays in some bulbous ornamentals. Ind. J. Genet. Plant Breed., 36: 230-237.
Younis, S.E.A. and Borham, J.H. 1975. The effects of gammairradiation on Polianthes tuberosa. Egypt J. Bot., 18(1,3): 205- 217.

Zizzo, G.V., Fascella, G. and Agnello, S. 1999. Effect of bulb size and planting date on flower yield and quality of tuberose grown in cold greenhouse for winter-spring production (Polianthes tuberosa L.-Sicily)"'. Colture Protette, 28(4): 71-74. 
